\title{
TANGGUNG JAWAB PELAKU USAHA TERHADAP PEKERJA/BURUH TERKAIT KETERLAMBATAN PEMBAYARAN UPAH LEMBUR
}

\author{
Oleh: \\ I Dewa Ayu Mirah Octaviani* \\ I Wayan Suardana** \\ Program Kekhususan Hukum Bisnis Fakultas Hukum \\ Universitas Udayana
}

\begin{abstract}
ABSTRAK
Pekerjaan adalah salah satu kebutuhan manusia dengan tujuan memperoleh upah. Upah adalah imbalan atas tenaga yang dikeluarkan pekerja. Persoalan mengenai upah masih banyak terjadi sampai saat ini. Pekerja/buruh yang bersedia bekerja melebihi waktu jam kerja ia berhak memperoleh upah lembur, namun dalam beberapa kasus salah satunya pada karyawan PT Newmont Nusa Tenggara (NNT) dimana upah lembur pekerja tersebut lambat dibayarkan. Maka dari itu disini penulis mencoba membahas mengenai akibat hukum bagi pelaku usaha yang melakukan keterlambatan pembayaran upah lembur terhadap pekerja/buruh dam upaya hukum yang dapat ditempuh oleh pekerja jika upah lemburnya tidak dibayarkan perusahaan. Dalam penulisan karya ilmiah ini metode yang digunkana yaitu metode penelitian hukum normatif yaitu metode yang bersumber dari peraturan perundang-undangan dan bahan kepustakaan. Hasil dari penelitian ini adalah akibat hukum yang diterima pelaku usaha terkait keterlambatan pembayaran upah lembur yaitu dapat dikenakan sanksi denda sesuai persentasi upah pekerja/buruh, sanski administratif apabila sudah diatur dalam perjanjian kerja dan uapaya hukum yang dapat ditempuh melalui Undang-Undang Nomor 2 Tahun 2004 tentang Penyelesaian Perselisihan Hubungan Industrial. Mengenai upaya hukum yang dapat ditempuh pekerja/buruh apabila upah lembur tidak juga dibayarkan yaitu
\end{abstract}

* I Dewa Ayu Mirah Octaviani, merupakan Mahasiswa Fakultas Hukum Universitas Udayana, ayumirah@yahoo.com. Udayana.

** I Wayan Suardana, merupakan Dosen Fakultas Hukum Universitas 
melalui perundingan bipartit, konsiliasi dan arbitrase untuk mencapai mufakat, jika cara tersebut gagal dilakukan maka salah satu pihak dapat mengajukan gugatan kepada Pengadilan hubungan Industrial setempat.

Kata Kunci: Pekerja; Upah Lembur; Kebijakan Pemerintah; Upaya Hukum

\begin{abstract}
ABSTRAC
Job is one of human needs with the aim of obtaining wages. Wages are rewards for labor released by workers. The issue of wages still occurs to this day. Workers who are willing to work more than their working hours are entitled to overtime wages, but in some cases one of them is PT Newmont Nusa Tenggara (NNT) employees where the overtime wages are paid. Therefore here the author tries to discuss the legal consequences for business actors who delay payment of overtime wages for workers / workers and legal remedies that can be taken by workers if the overtime wages are not paid by the company. In writing this scientific paper the method used is the normative legal research method, namely the method derived from legislation and literature. The results of this study are the legal consequences received by business actors related to late payment of overtime wages which can be subject to fine sanctions according to the percentage of workers' wages, administrative sanctions if it has been stipulated in work agreements and legal remedies that can be taken through Law Number 2 of 2004 concerning Settlement of Industrial Relations Disputes. Regarding legal remedies that can be taken by workers if overtime pay is also not paid, namely through bipartite negotiation and conciliation to reach consensus, if this method fails, one party can file a lawsuit with the local Industrial Relations Court.
\end{abstract}

Keywords: Workers; Overtime Wages; Government policy; Legal effort

\title{
I.PENDAHULUAN
}

\subsection{Latar Belakang}

Pekerjaan adalah kebutuhan yang sangat diperlukan manusia guna kelangsungan hidupnya. Setiap manusia berhak menentukan pekerjaanya sesuai bidangnya masing-masing. Dewasa ini manusia memiliki kebutuhan yang begitu banyak. 
Guna memenuhi kebutuhan inilah manusia harus bekerja. Pasal 27 ayat (2) Undang-Undang Dasar Negara Republik Indonesia 1945 telah menyebutkan setiap warga negara tanpa terkecuali berhak memperoleh pekerjaan dan penghidupan yang layak bagi kemanusiaan, dengan adanya jaminan ini tentu menusia berhak memperoleh pekerjaan yang layak tanpa adanya diskriminasi guna kesejahteraan diri sendiri maupun keluarganya. Dalam hubungan kerja tentu adanya hak dan kewajiban yang harus dipenuhi oleh masing-masing pihak. Hak dan kewajiban merupakan suatu kewenangan yang diberikan kepada seseorang oleh hukum. ${ }^{1}$

Dalam hubungan kerja tersebut terjadilah perjanjian antara perusahaan dengan pekerja/buruh yaitu mengenai perjanjian pihak kesatu (buruh) bekerja dengan mendapat imbalan upah dan pihak kedua (majikan) wajib memberikan pekerjaan dengan membayarkan upah. Tujuan dasar pekerja untuk bekerja adalah memperoleh upah sebagai imbalan atas tenaga yang telah dikeluarkan. Menurut Pasal 1 angka 30 Undang-Undang Nomor 13 Tahun 2003 tentang Ketenagakerjaan (UU Ketenagakerjaan) upah adalah hak yang diterima pekerja/buruh yang ditetapkan dan dibayarkan menurut suatu perjanjian kerja, kesepakatan atau peraturan perundang-undangan, termasuk untuk tunjangan bagi pekerja/buruh dan keluarganya atas suatu pekerjaan dan/atau jasa yang telah atau akan dilakukan. Upah ini merupakan faktor utama dari perjanjian kerja, karena sasaran yang paling penting bagi pekerja yaitu memperoleh upah, dimana upah sangat penting guna menunjang kesejahteraan hidupnya, menghidupi pekerja maupun keluarganya demi kelangsungan hidup. ${ }^{2}$

${ }^{1}$ Ishaq, 2007, Dasar-Dasar Ilmu Hukum, Sinar Grafika, Jakarta, h. 82.

${ }^{2}$ Darwan Prinst, 2000, Hukum Ketenagakerjaan Indonesia, Cet. II, PT. Citra Aditya Bakti, Bandung, h.213. 
Mengenai masalah keterlambatan pembayaran upah lembur masih sangat sering terjadi contohnya dalam sebuah kasus pada karyawan PT Newmont Nusa Tenggara (NNT) dimana uang lembur telah lambat dibayarkan oleh perusahaan mereka bekerja sejak tahun 1999 sampai dengan 2004 dimana pekerja yang telah melakukan kerja yang dilihat dari perspektif hukum telah bekerja di luar jam kerja seharusnya. ${ }^{3}$ Tentu hal ini sangat merugikan pekerja, dimana hak-haknya telah di langgar oleh perusahaan tempatnya bekerja. Masalah mengenai keterlambatan pembayaran upah diatur dalam Pasal 95 ayat (2) UU Ketenagakerjaan yang menyatakan bahwa, "Pengusaha yang karena kesengajaan atau kelalaiannya mengakibatkan keterlambatan pembayaran upah, dikenakan denda sesuai dengan presentase tertentu dari upah pekerja/buruh". Ditinjau dari Pasal 95 ayat (2) UU Ketenagakeraan tersebut maka tidak ada atau adanya kekosongan norma mengenai tanggung jawab pelaku usaha akibat keterlambatan pembayaran upah lembur terhadap pekerja/buruh. Dengan demikian penting untuk melakukan penelitian terhadap tanggung jawab pelaku usaha terhadap pekerja/buruh akibat keterlambatan pembayaran upah lembur.

\subsection{Rumusan Masalah}

Melalui ulasan latar belakang di atas, maka penulis mencoba merumuskan beberapa permasalahan yang perlu dibahas lebih jauh, yaitu:

${ }^{3}$ detikNews, 2005, Upah Lembur Tak Dibayar Karyawan Newmont Lapor ke Polisi, URL : https://news.detik.com/berita/d-335837/upah-lembur-takdibayar-karyawan-newmont-lapor-ke-polisi- Diakses tanggal 12 Januari 2018 
1. Apa akibat hukum bagi pelaku usaha yang melakukan keterlambatan pembayaran upah lembur terhadap pekerja/buruh?

2. Upaya hukum apa yang dapat ditempuh pekerja apabila upah lemburnya tidak dibayarkan?

\section{ISI MAKALAH}

\subsection{Metode Penelitian}

Dalam penulisan karya ilmiah ini metode penelitian yang digunakan adalah penelitian normatif atau penelitian hukum doktrinial yang bersumber dari bahan hukum primer dan skunder yaitu dari peraturan perundang-undangan yang disebut dengan bahan hukum primer serta bahan kepustakaan sebagai bahan hukum skunder. Penelitian hukum normatif akan menggunakan isu dari hukum untuk dijadikan sistem norma untuk pusat kajiannya dengan pemberian suatu argument hukum untuk menentukan apakah suatu peristiwa sudah benar atau salah. ${ }^{4}$

\subsection{Hasil dan Analisis}

\subsubsection{Akibat Hukum Bagi Pelaku Usaha Yang Melakukan}

\section{Keterlambatan Pembayaran Upah Lembur terhadap Pekerja/Buruh}

Dewasa ini manusia banyak memiliki kebutuhan baik kebutuhan primer maupun sekunder. Salah satu kebutuhan yang paling penting guna menunjang kelangsungan hidupnya maupun keluarganya yaitu pekerjaan. Dengan bekerja seseorang akan memperileh imbalan dalam bentuk uang. Imabaln atau upah adalah timbal balik yang diberikan perusahaan atas tenaga yang

${ }^{4}$ Mukti Fajar dan Yulianto Achmad, 2009, Dualisme Penelitian Hukum Normatif Dan Empiris, Pustaka Pelajar, Yogyakarta, h. 36 
dikeluarkan pekerja/buruh. Pasal 28D ayat (2) UUD 1945 menerangkan bahwa setiap orang tanpa terkecuali berhak bekerja serta mendapat imbalan dengan diperlakukan adil dan layak di dalam hubungan kerja. Hak disini dikaitkan dengan pengertian hak asasi manusia yaitu suatu kebebabasan individuyang dimilikinya dengan keleluasan. ${ }^{5}$ Perlindungan tenaga kerja untuk menjamin hak pekerja/buruh serta menjamin kesempatan tanpa adanya diskriminasi untuk menjamin kesejahteraan pekerja/buruh dan keluarganya. ${ }^{6}$ Dalam hubungan kerja adanya kedudukan majikan lebih tinggi dari pada pekerja/buruh dimana sering akan terjadi ketidakseimbangan salah satunya mengenai pengupahan. Dalam hal pekerja yang bersedia bekerja di luar jam kerja berhak menerima upah di luar upah pokoknya dan perusahaan wajib memenuhi hak pekerja tersebut.

UU Ketenagakerjaan telah mengatur mengenai pengupahan yaitu terdapat dalam Pasal 88 ayat (3) UU Ketenagakerjaan, meliputi :

a. upah minimum artinya upah yang pas diperoleh pekerja sesuai peraturan yang berlaku.

b. upah kerja lembur, yitu mengenai upah selain upah semestinya karena pekerja telah melakukan kerja lembur

c. pekerja berhak memperoleh upah walaupun berhalangan untuk bekerja.

d. upah tidak masuk kerja karena melakukan kegiatan lain di luar pekerjaannya

${ }^{5}$ I Made Udiana, 2018, Industrialisasi Dan Tanggungjawab Pengusaha Terhadap Tenaga Kerja Terlibat Hukum, Cet. I, Udayana University Press, Denpasar, h. 26.

6I Made Dwi Anugrah Putra, Pelaksanaan Hak-Hak Pekerja Harian Lepas Pada Hotel Bintang Bali Resort, Jurnal Fakultas Hukum Universitas Udayana, Bali. 
e. pekerja berhak memperoleh upah karena menjalankan hak waktu istirahat kerjanya

f. bagaimana bentuk dan cara pembayaran upah

g. denda dan potongan upah

h. apa saja hal-hal yang dapat diperhitungkan dengan upah

i. struktur dan skala pengupahan yang profesional bagi pekerja

j. pekerja berhak memperoleh upah untuk pembayaran pesangon, dan

k. upah untuk perhitungan pajak pengahasilan

Terkait permasalahan mengenai akibat hukum pelaku usaha atas keterlambatan pembayaran upah lembur UU Ketenagakerjaan hanya mengatur mengenai keterlambatan pembayaran upah saja yaitu terdapat dalam Pasal 95 ayat (2) UU Ketenagakerjaan yang menyatakan bahwa Pengusaha yang karena kesengajaan atau kelalaiannya mengakibatkan keterlambatan pembayaran upah, dikenakan denda sesuai dengan presentase tertentu dari upah pekerja/buruh. Adanya pasal ini membuktikan bahwa keterlambatan pembayaran upah oleh pengusaha terhadap pekerja/buruh merupakan tindakan yang dilarang menurut perundang - undangan. Melalui Pasal 33 Peraturan Pemerintah Nomor 78 tahun 2015 tentang Pengupahan menyatakan bahwa upah kerja lembur sebagaimana dimaksud didalam Pasal 3 huruf b mewajibkan pengusaha untuk membayar pekerja/buruh yang bekerja melebihi waktu kerja atau pada waktu istirahat mingguan atau pada hari libur resmi sebagai bentuk kompensasi kepada pekerja/buruh sesuai dengan ketentuan peraturan perundangundangan. Ditinjau dari Pasal 95 ayat (2) UU Ketenagakerjaan dalam pengaturan norma-normanya belum bisa menjawab mengenai permasalahan akibat hukum bagi pelaku usaha yang 
melakukan keterlambatan pembayaran upah lembur terhadap pekerja/buruh.

Berpedoman pada Pasal 95 ayat (2) UU Ketenagakerjaan akibat hukum bagi pelaku usaha akibat keterlambatan pembayaran upah lembur terhadap pekerja/buruh merupakan konsekuensi dari peristiwa yang terjadi. Akibat hukum yang diterima pelaku usaha adalah berupsa sanksi denda sesuai dengan persentase tertentu dari upah pekerja/buruh. Apabila sanski denda tersebut tidak dilaksanakan oleh pelaku usaha maka dapat dikenakan sanksi administratif seperti yang diatur dalam Pasal 59 ayat (1) huruf d PP Pengupahan, yang menyatakan bahwa: "Sanksi Administratif dikenakan kepada pengusaha yang tidak membayar upah sampai melewati jangka waktu", dan huruf e yang menyebutkan bahwa: "Sanksi Administratif dikenakan kepada pengusaha yang tidak memenuhi kewajibannya untuk membayar denda". Namun apabila keterlambatan pembayaran upah lembur pekerja/buruh masih sering terjadi dan pengenaan sanksi denda tidak kunjung terlaksana guna melindungi hak atas upah pekerja/buruh, maka pekerja/buruh atau serikat pekerja/buruh dapat melakukan upaya hukum. ${ }^{7}$

\subsubsection{Upaya Hukum Yang Dapat Ditempuh Pekerja Apabila Upah Lemburnya Tidak Dibayarkan}

Di dalam dunia kerja konflik adalah hal biasa yang dapat dijumpai. Adanya hak dan kewajiban dalam perjanjian kerja tidak sedikit akan menimbulkan sebuah perselisihan. Perselisihan dalam dunia kerja disebut juga dengan perselisihan hubungan

7 Putu Gede Aditya Wangsa, KeterlambatanPembayaran Upah Pekerja oleh PT Boma Bisma Indra (Persero) Surabaya menurut Undang-Undang Nomor 13 Tahun 2003 tentang Ketenagakerjaan, Jurnal Fakultas Hukum Universitas Udayana, Bali 
industrial. Apabila pekerja sudah bersedia bekerja melampaui batas waktu maka pekerja/buruh tersebut berhak memperoleh upah lembur. Upah tersebut inilah yang harus diperjuangkan oleh pekerja karena ia telah bersedia mengeluarkan tenaganya untuk bekerja dari waktu semestinya. Pengusaha yang tidak membayarkan upah lembur kepada pekerja/buruh dapat dikenakan sanksi pidana penjara/denda. Berdasarkan Pasal 187 UU Ketenagakerjaan Sanksi pidana penjara, kurungan dan/atau denda tidak menghilangkan kewajiban pengusaha membayar hak dan/atau ganti kerugian kepada pekerja/buruh. Maka dari itu pekerja/buruh masih bisa melakukan upaya hukum yang sesuai untuk memperjuangkan hak-haknya terutama di dalam pengupahan. 8

Dengan pertimbangan dasar hukum bahwa kerja lembur merupakan hak dari pekerja/buruh. Pekerja boleh saja menolak kerja lembur tersebut karena kerja lembur tidak boleh dipaksakan. Pekerja/buruh yang bersedia bekerja melebihi batas waktunya berhak memperoleh uang kerja lembur yang merupakan hak berdasarkan hukum. Karyawan berhak mendapat bayaran dari majikannya, apabila ia tidak memperoleh bayaran maka keryawan dapat menuntut haknya melalui lembaga formil atas bayaran yang tidak diperoleh tersebut. ${ }^{9}$ Indonesia telah memiliki suatu peraturan yang menyelesaian perselisihan dalam sebuah hubungan kerja. Yaitu melalui Undang-Undang Nomor 2 Tahun 2004 mengenai Penyelesaian Perselisihan Hubungan Industrial (selanjutnya disingkat UU Penyelesaian Perselisihan Hubungan Industrial). Pasal 2 UU Penyelesaian Perselisihan Hubungan

8I Made Ratna Arianta, Penyelesaian Perselisihan Pemberian Upah Jam Kerja Lembur Bagi Pekerja Di Villa Cepaka Mas Badung, Jurnal Fakultas Hukum Universitas Udayana, Bali.

${ }^{9}$ Peter Mahmud Marzuki, 2016, Pengantar Imu Hukum, Prenadamedia Group, Jakarta, h.141. 
Industrial menyebutkan beberapa jenis perselisihan dalam hubungan kerja yaitu :

1. perselisihan mengenai hak;

2. perselisihan mengenai kepentingan;

3. perselisihan mengenai pemutusan hubungan kerja; dan

4. perselisihan yang mengenai hubungan antara serikat pekerja/serikat buruh/ hanya dalam satu perusahaan.

Pekerja yang sudah bersedia melakukan kerja lembur namun tidak dibayarkan upah lemburnya oleh perusahaan maka hal ini disebut dengan perselisihan mengenai hak. Yang dimaksud Perselisihan hak yaitu perselisihan yang timbul dikarenakan tidak terpenuhinya sebuah hak akibat adanya suatu perbedaan pelaksanaan peraturan perundang-undangan yang berlaku, pelaksanaan perjanjian kerja atau peraturan perusahaan yang berlaku.Untuk memperjuangkan haknya untuk mendapat uang kerja lembur yang tidak dibayarkan oleh perusahaan maka pekerja/buruh dapat melakukan beberapa upaya hukum.

UU Penyelesaian Perselisihan Hubungan Industrial telah memberikan beberapa penyelesaian perselisihan dalam sebuah hubungan industrial yaitu :

a. Penyelesaian Melalui Bipartit

Dalam sebuah penyelesaian perselisihan hak hubungan industrial para pihak yaitu pelaku usaha, pekerja/buruh atau srikat buruh wajib melakukan perundingan bipartit dengan jangka waktu 30 (tiga puluh) hari, jika dalam waktu 30 (tiga puluh) hari tersebut salah satu dari pihak tidak melaksanakan suatu perundingan atau telah melakukan perundingan tetapi tidak tercapainya suatu kesepakatan maka perundinga bipartit tersebut dianggap gagal. 
b. Penyelesaian dengan Mediasi

Mediasi merupakan penyelesaian perselisihan hak dalam hubungan industrial dalam satu perusahaan mengenai perselisihan hak. Baik hak pekerja maupun hak pemberi kerja.

c. Penyelesaian dengan Konsiliasi

Konsilias merupakan penyelesaian perselisihan hak dalam satu perusahan mengenai perselisihan kepentingan melalui musyawarah yang ditangani oleh seorang konsiliator yang netral, artinya tidak berpihak kepada salah satu pihak saja.

d. Penyelesaian dengan cara Arbitrase

Arbitrase merupakan suatu penyelesaian perselisihan di luar Pengadilan Hubungan Industrial dengan cara kesepakatan tertulis oleh para pihak yang berselisih dengan penyerahan perselisihan tersebut kepada arbiter dengan keputusan para pihak yang mengikat dan bersifat final.

UU Penyelesaian Perselisihan Hubungan Industrial menjelaskan bahwa pekerja/buruh atau serikat pekerja/buruh dapat melakukan upaya hukum melalui Pengadilan Hubungan Industrial. Penyelesaian perselisihan di luar pengadilan di atur dalam Pasal 3 mengenai penyelesaian melalui Bipartit, Pasal 17 mengenai penyelesaian melalui Konsiliasi, dan Pasal 29 menenai penyelesaian melalui Arbitrase UU Penyelesaian Perselisihan Hubungan Industrial. ${ }^{10}$ Tata cara mengenai penyelesaian perselisihan hubungan industrial ini diatur dalam ketentuan Pasal 3 sampai Pasal 54 UU Penyelesaian Perselisihan Hubungan Industrial Penyelesaian perselisihan hubungan industrial baik antara pekerja/buruh dengan perusahaan wajib diselesaikan

${ }^{10}$ I Made Udiana, Kedudukan Dan Kewenangan Pengadilan Hubungan Industrial, Cet. II, Udayana University Press, Denpasar, h.10. 
terlebih dahulu melalui Perundingan Bipartit secara musyawarah untuk mencapai mufakat (Pasal 3 UU PPHI). Apabila dalam hal perundingan bipartite gagal, maka dapat dilanjutkan penyelesaian melalui konsiliasi atau arbitrase pada instansi yang bertanggung jawab dibidang ketenagakerjaan setempat dengan melampirkan bukti bahwa upaya - upaya penyelesaian melalui perundingan bipartit telah dilakukan namun gagal. Dalam hal para pihak tidak menetapkan pilihan penyelesaian melalui konsiliasi atau arbitrase, maka instansi yang bertanggung jawab dibidang ketenagakerjaan melimpahkan penyelesaian perselisihan kepada mediator. Apabila dalam hal penyelesaian melalui konsiliasi dan mediasi tidak mencapai kesepakatan, maka salah satu pihak dapat mengajukan gugatan kepada Pengadilan Hubungan Industrial (Pasal 4 UU PPHI).

\section{Penutup}

\subsection{Kesimpulan}

Berdasarkan pembahasan mengenai permasalahn diatas dapat ditarik kesimpulan sebagai berikut :

1. Pelaku usaha yang melakukan keterlambatan pembayaran upah lembur kepada pekerja/buruh dapat dikenakan akibat hukum berupa sanksi denda. Apabila sanski denda tersebut tidak dilaksanakan oleh pelaku usaha maka dapat dikenakan sanksi administratif. Sanksi administratif baru dapat dikenakan apabila sudah diatur dalam perjanjian kerja tersebut.

2. Pekerja/buruh yang mempunyai konflik dalam hubungan kerja dengan pelaku usaha dapat melakukan upaya hukum untuk mendapatkan haknya atas upah lembur yang tidak 
dibayarkan oleh perusahaan yaitu dengan cara penyelesaian perselisihan bipartit, mediasi, konsiliasi, atau arbitrase.

\subsection{Saran}

1. Pelaku usaha sebaiknya melaksanakan kewajiban dalam hal pembayaran upah lembur tepat pada waktunya kepada pekerja/buruh dikarenakan upah lembur tersebut sangat penting bagi pekerja/buruh guna kelangsungan hidupnya maupun keluarganya.

2. Pelaku usaha sebaiknya melakukan kewajiban dalam pembayaran upah lembur kepada pekerja/buruh agar nantinya tidak terjadi sebuah konflik dalam hubungan kerja mengenai hak pekerja dalam memperoleh upah lembur.

\section{DAFTAR PUSTAKA}

\section{Buku-Buku :}

Darwan Prinst, 2000, Hukum Ketenagakerjaan Indonesia, Cet. II, PT. Citra Aditya Bakti, Bandung.

Udiana I Made , 2018, Industrialisasi Dan Tanggungjawab Pengusaha Terhadap Tenaga Kerja Terlibat Hukum, Cet. I, Udayana University Press, Denpasar.

Udiana I Made, Kedudukan Dan Kewenangan Pengadilan Hubungan Industrial, Cet. II, Udayana University Press, Denpasar.

Ishaq, 2007, Dasar-dasar Ilmu Hukum, Sinar Grafika, Jakarta.

Mukti Fajar dan Yulianto Achmad, 2009, Dualisme Penelitian Hukum Normatif Dan Empiris, Pustaka Pelajar, Yogyakarta.

Peter Mahmud Marzuki, 2016, Pengantar Ilmu Hukum, Prenadamedia Group, Jakarta.

\section{Jurnal Ilmiah :}

Dwi Anugrah Putra I Made, Pelaksanaan Hak-Hak Pekerja Harian Lepas Pada Hotel Bintang Bali Resort, Jurnal Fakultas Hukum Universitas Udayana, Bali.

Ratna Arianta I Made, Penyelesaian Perselisihan Pemberian Upah Jam Kerja Lembur Bagi Pekerja Di Villa Cepaka Mas Badung, Jurnal Fakultas Hukum Universitas Udayana, Bali. 
Aditya Wangsa Putu Gede, Keterlambatan Pembayaran Upah Pekerja oleh PT Boma Bisma Indra (Persero) Surabaya menurut Undang-Undang Nomor 13 Tahun 2003 tentang Ketenagakerjaan, Jurnal Fakultas Hukum Universitas Udayana, Bali

\section{Internet :}

detikNews, 2005, Upah Lembur Tak Dibayar Karyawan Newmont Lapor ke Polisi, URL : https://news.detik.com/berita/d335837/upah-lembur-tak-dibayar-karyawan-newmontlapor-ke-polisi- Diakses tanggal 12 Januari 2018.

\section{Peraturan Perundang-Undangan :}

Undang-Undang Dasar Negara Republik Indonesia Tahun 1945 Undang-Undang Nomor 13 tahun 2003 tentang Ketenagakerjaan Undang-Undang Republik Indonesia Nomor 2 Tahun 2004 tentang Penyelesaian Perselisihan Hubungan Industrial Peraturan Pemerintah Nomor 78 Tahun 2015 tentang Pengupahan 